\title{
Tissue Oxygen Available as a Criterion for the Effectiveness of Continuous Positive Pressure Breathing
}

\author{
ANTHONY V. BERAN, (') ROBERT F. HUXTABLE, KENNETH G. PROCTOR, AND DONALD R. \\ SPERLING \\ Department of Pediatrics, College of Medicine, University of California, Irvine, California, USA
}

\begin{abstract}
Summary
As little as 3-5 cm $\mathrm{H}_{2} \mathrm{O}$ increase in proximal airway pressure applied to normal lung reduces cardiac output. It is postulated that decreased pulmonary compliance in respiratory distress syndrome (RDS) acts as a barrier thus offsetting this effect. Since cardiac output is not routinely measured, severe reduction in it could accompany regression of disease while maintaining the same airway pressure. This study was undertaken to determine whether tissue oxygen available $\left(\mathrm{O}_{2} \mathrm{a}\right)$ could be used to detect changes in perfusion during continuous positive pressure breathing (CPPB). CPPB was evaluated in 10 normal rabbits $\left(C_{\mathrm{L}}=9.5 \pm 1.8 \mathrm{cc} / \mathrm{g}\right.$ at $\left.25 \mathrm{~cm} \mathrm{H}_{2} \mathrm{O}\right)$ and in 10 pulmonarydamaged rabbits $\left(\mathrm{C}_{\mathrm{L}}=5.5 \pm 1.4 \mathrm{cc} / \mathrm{g}\right.$ at $\left.25 \mathrm{~cm} \mathrm{H}_{2} \mathrm{O}\right)$ produced by subjecting them to $100 \% \mathrm{O}_{2}$. Airway pressure was increased from 0-15 cm $\mathrm{H}_{2} \mathrm{O}$ in $3 \mathrm{~cm} \mathrm{H} \mathrm{H}_{2} \mathrm{O}$ increments at 10-min intervals. $\mathrm{O}_{2} \mathrm{a}$ and $\mathrm{PaO}_{2}$ were monitored continuously. In the normal group, $\mathrm{O}_{2}$ a decreased at $3 \mathrm{~cm} \mathrm{H}_{2} \mathrm{O}$ airway pressure, reaching $22 \%$ of control at $12 \mathrm{~cm} \mathrm{H}_{2} \mathrm{O}$, at which pressure $\mathrm{PaO}_{2}$ decreased. Breathing $100 \% \mathrm{O}_{2}$ at this airway pressure increased $\mathrm{PaO}_{2}$ to $408 \mathrm{~mm} \mathrm{Hg}$, whereas $\mathrm{O}_{2}$ a returned to $45 \%$ of control. In the experimental group, $\mathrm{O}_{2}$ a decreased at $9 \mathrm{~cm} \mathrm{H}_{2} \mathrm{O}$ airway
\end{abstract}

pressure, at $12 \mathrm{~cm} \mathrm{H}_{2} \mathrm{O}$ it was $36 \%$ of control at which pressure $\mathrm{PaO}_{2}$ decreased slightly. Breathing $100 \% \mathrm{O}_{2}$ at this airway pressure increased $\mathrm{PaO}_{2}$ to $316 \mathrm{~mm} \mathrm{Hg}$, and increased $\mathrm{O}_{2}$ a to $200 \%$ of control. These data indicate that with excessive airway pressure, muscle hypoxia may exist during systemic hyperoxemia and that a low compliance lung exerts a protective effect on $\mathrm{O}_{2} \mathrm{a}$. Since changes in cardiac output during CPPB are compliance dependent, and since $\mathrm{O}_{2} \mathrm{a}$ is perfusion dependent, tissue oxygen available could provide a means of selecting optimal airway pressure during CPPB.

\section{Speculation}

This study indicates that in the presence of normal $\mathrm{PaO}_{2}$ or every hyperoxemia, an excessive increase in airway pressure can produce a decrease in cardiac output and local oxygen supply to the tissues. The airway pressure required to produce optimal oxygenation without interference with cardiac output is lung compliance dependent. For the most efficient application of CPPB in clinical situations, measurement of physiologic variables which would reflect changes in perfusion in addition to systemic oxygenation are suggested. 
INTRODUCTION

Since Gregory's report (4) on the ef fectiveness of CPPB for treatment of infants with Respiratory Distress Syndrome (RDS), this method has been accepted throughout the world. This method of treatment provides increased proximal airway pressure (AP) sufficient to prevent alveolar collapse at the end of expiration, while the subject breathes spontaneously. In the normal lung, as 11ttle as $3-5 \mathrm{~cm} \mathrm{H} \mathrm{H}_{2} \mathrm{O}$ AP may reduce cardiac output $(\dot{Q})(1,8)$. Contrary to this, 1t is postulated that in RDS, decreased pulmonary compliance $\left(C_{L}\right)$ acts as a barrier and minimizes this ef fect. Pulmonary compliance varies widely between normal subjects and those with RDS of varying severity. Therefore, a wide range of AP 18 required to provide optimal oxygenatfion without reducing $Q$.
since $Q$ is not routinely measured, a reduction in $Q$ could occur unnoticed following an excessive increase in $A P$. In addition, a reduction in $\dot{Q}$ could occur concommitantly with a regression of the disease, when lung compliance improves and proximal alrway pressure remains unchanged.

Micropolarographic oxygen electrodes have been used to measure the state of oxygenation of different organs, and have been accepted as a very useful research technique $(2,6,7)$. If the micro oxygen electrode is placed in a tissue area of an active muscle, characterlzed by h1gh oxygen consumption, normal $A-V$ $\mathrm{PO}_{2}$ difference and no preferential blood flow, and if the oxygen consumption of the electrode does not interfere with normal cellular metabolism, then such an electrode would measure changes in tissue
flecting changes in both $\mathrm{PaO}_{2}$ and perfusion.

Th1s atudy was undertaken to determine whether $\mathrm{O}_{2}$ a could be used to detect
changes in perfusion when excessive AP 18 applfed during CPPB. In addition, changes in perfusion when excessive AP is applied during CPPB. In addition, the mechanisms by which perfusion is affected during excessive increase in AP
are elucidated. METHODS AND MATERIALS

Thitteen adult male New Zealand rabbits $(1.8-2.6 \mathrm{~kg})$ were divided Into two groups. The control group (N) consisted of 10 animals with normal lungs and the experimental group (E) consisted of 10 animals with lungs damaged by exposure to high oxygen concentrations for 36 to 48 hours (3). Individual animal
in the experimental group were placed in a chamber with adequate food and water and normobaric $100 \% 0_{2}$ clrculating at $61 / \mathrm{min}$. After 36 to 48 hours, the animals were removed from the chamber and exposed to room a1r for one to three hours before the inftiation of any experimental procedure.

Animals were anesthetized with intravenous sodium pentobarbital $(25 \mathrm{~mm} / \mathrm{kg})$ and placed on a heating pad (Gorman Rupp $K-1$ ) with pad temperature maintained at
$39^{\circ} \mathrm{C}$. A tracheostomy tube was inserted and secured. A 5 F arter1al catheter containing a monopolar oxygen sensor (International B1ophysics Corporation, Irvine, California - IBC) was advanced from the femoral artery to a point dista1 to the aortic bifurcation for monitoring of blood pressure (BP), arterial partial oxygen pressure $\left(\mathrm{PaO}_{2}\right)$, and for blood sample collection. A venous catheter was advanced from the femoral vein into the rtght atrium for pressure
measurement (Pra) and blood sample collectlon. Q was determined by the Fick principle.

A balloon secured to PE 260 tubing was inserted orally to the cardiac sphincter and then withdrawn to the lower $1 / 3$ of the esophagus for measurement of esophageal pressure (Pes). A monopolar oxygen electrode was Implanted into the right triceps muscle for measurement of $\mathrm{O}_{2} \mathrm{a}$. Reference electrodes were secured to the skin and connected to the monitoring systems.

Specifics related to construction, Implantation and performance of the oxygen electrode were described previousiy $(2,6-8)$. For measurement of cortical $\mathrm{O}_{2} \mathrm{a}$, oxygen sensitive electrodes were Implanted in three normal rabbits. Holes were drilled in the skulls of the animals and electrodes were inserted into the parletal area of the cortex. The electrodes were soldered to external connect-
or $\mathrm{s}$ which then were fixed to the skull with stainless steel screws and dental or $s$ which then were fixed to the skull with stainless steel screws and dental
cement. Approximately 7-10 days were allowed for complete animal recovery, afcement. Approximately $7-10$ days were allowed
ter which the CPPB experiment was performed. The tracheostomy tube was connected to a pneumotachograph in a series with a
CPPB system simllar to the one described by Gregory (4). The system consisted of (a) a rigid wall, cylindric $200 \mathrm{cc}$ reservolr with a needle valve exhaust regulator, flowneter, subject connector and adapters for measurement of system pressure, oxygen concentration and total system outflow, (b) exchangeable com-
pliant $200 \mathrm{cc}$ rubber bag placed in front of a rigid wall reservolr, and (c) a pressure release "pop of f" system in the form of a submersible water monometer placed proximally to the rigid wall reservoir. A humidified airflow of $121 /$ min. was circulated through the system. Control values for all phystologic var1ables measured were obtained at this
point. AP was then increased from 0.5 to $15 \mathrm{~cm} \mathrm{H}_{2} \mathrm{O}$ in $3 \mathrm{~cm}$ increments at 10 minute intervals. At $12 \mathrm{~cm} \mathrm{H}_{2} \mathrm{O}$, the fraction of inspired $\mathrm{O}_{2}\left(\mathrm{~F}_{10}\right)$ was increased from amblent to $50 z$ and $100 z$. During these procedures, animals were
breathing spontaneously and regulating their own respiratory rates and tidal volumes.

To verify the validity of the experimental model, static lung compliance $\left(C_{L}\right)$ of the exterforized lung and histologic evaluations were performed in six normal and a1x oxygen-treated animals not exposed to CPPB. Also, $C_{2}$ of the exter lorized lungs was measured in all animals exposed to CPPB immediately after death. To permit comparison of lungs of d
as ml of gas per gram of lung tissue (5).

Arterial (BP) and right atrial (Pra) pressures, resplratory rate (RR), tidal volume $\left(\mathrm{V}_{\mathrm{T}}\right)$, minute volume $\left(\mathrm{V}_{\mathrm{E}}\right)$, $\mathrm{FeO}_{2}$, arteriai and venous $\mathrm{pH}$ and partial $\mathrm{O}_{2}$ consumption ( $\left.\mathrm{VO}_{2}\right)$, cardlac output $(\hat{\mathrm{Q}})$, and static lung compliance $\left(\mathrm{C}_{\mathrm{L}}\right.$ ) were deconsumption $\left(\mathrm{vO}_{2}\right)$, cardlac output $(\mathrm{Q})$, and static lung compliance $\left(\mathrm{C}_{\mathrm{L}}\right)$ were de-
termined as previously described (3). Student T-test was performed to determine the statistical differences between the control and experimental groups. RESULTS

$C_{L}$ at the peak inflation pressures at $25 \mathrm{~cm} \mathrm{H} \mathrm{H}_{2} \mathrm{O}$ was $9.5 \pm 1.8 \mathrm{cc} / \mathrm{g}$ of tissue in the control group and $5.5 \pm 1.4 \mathrm{cc} / \mathrm{g}$ of t1ssue in the experimental group. The
ratio of lung weight to body weight $(\mathrm{gr} / \mathrm{kg})$ in the control and experimental anratio of lung weight to body weight ( $(\mathrm{gr} / \mathrm{kg})$
imal groups was not signigicantly different.

At this pressure the normal lung appeared fully inflated whlle the damaged lung demonstrated multiple lobulation surrounded by uninflated segments of tissue. The slope of the pressure volume curve over the entire range was reduced in the damaged lung. Histologic evaluation of damaged lungs showed pulmonary hemorrhage, atelectasis, and edema but no evidence of cellular atypla or hyaline membrane formation.

Mean Pra in the control and experimental groups was $4.2 \pm 0.8$ and $4.1 \pm 1.2 \mathrm{~cm}$ $\mathrm{H}_{2} \mathrm{O}$ respectively. Percent changes in Pra as a function of AP are shown in Fig.
1. Mean Pra in the control group increased with each increment in AP. The experimental group contrasted to this in that this increase in Pra did not occur until an AP greater than $6 \mathrm{~cm} \mathrm{H} \mathrm{H}_{2} \mathrm{O}$ was reached. At $6 \mathrm{~cm} \mathrm{H} \mathrm{H}_{2} \mathrm{O}$ the difference between the two groups was statistical1y gignificant $(t-9.58, p<0.005)$. At the maximum AP of $15 \mathrm{~cm} \mathrm{H}$, mean Pra for control and experimental groups was
$10.0 \pm 1.8 \mathrm{~cm} \mathrm{H} \mathrm{H}_{2} \mathrm{O}\left(240 \mathrm{Z}\right.$ of control) and $5.9 \pm 1.8 \mathrm{~cm} \mathrm{H}_{2} \mathrm{O}$ (140Z of control), respectively.

$\dot{Q}$ In control and experimental groups was $120 \pm 17 \mathrm{cc} / \mathrm{m} 1 \mathrm{n} / \mathrm{kg}$ and $273 \pm 43 \mathrm{cc} /$ $\mathrm{min} / \mathrm{kg}$ ( $\mathrm{p}<0.001$; $f=6.687$ ). Percent changes in $Q \mathrm{QB}$ a function of AP are shown in Fig. 2. Q in the control group decreased with each increment in AP. At $9 \mathrm{~cm} \mathrm{H} \mathrm{H}_{2} \mathrm{O}$ it had decreased to $60 \pi_{\text {, reaching } 22 \pi}$ of control at $15 \mathrm{~cm} \mathrm{H} \mathrm{H}_{2} \mathrm{OAP}$. In the experimental group. $Q$ remained essentially unchanged unt11 $9 \mathrm{~cm} \mathrm{H}_{2} \mathrm{OAP}$.
when subsequently it decreased, and at $15 \mathrm{~cm} \mathrm{H} \mathrm{H}_{2} \mathrm{OP} 1 \mathrm{t}$ was $57 \%$ of control.

Mean and standard deviation changes of $\mathrm{PaO}_{2}$ and $\mathrm{O}_{2}$ obtained at $0.5,3,6,9$, and $12 \mathrm{~cm} \mathrm{H} \mathrm{H}_{2} \mathrm{OAP}$ at an $\mathrm{FHO}_{2}$ of $20.9 \%$, and at an $\mathrm{FiO}_{2}$ of $50 \%$ and $100 \%$ at $12 \mathrm{~cm}$ $\mathrm{H}_{2} \mathrm{O}$ AP (which are presented in Table 1). In normal an1ma1s, $\mathrm{PaO}_{2}$ remained unchanged with increases in AP from 0.5 to $9 \mathrm{~cm} \mathrm{H}_{2} \mathrm{O}$. At $12 \mathrm{~cm} \mathrm{H}_{2} \mathrm{O}$ AP, 1 t was slightly decreased to $88 \mathrm{~mm} \mathrm{Hg}$. Simultaneously, with no change in $\mathrm{PaO}_{2}, \mathrm{O}_{2} \mathrm{a}$ decreased with each increment in A?, reaching 3 and $6 \mathrm{~cm} \mathrm{H} \mathrm{H}_{2} \mathrm{OP}$, decreased to control imental antma $18, \mathrm{PaO}_{2}$ Increased at 3 and $6 \mathrm{Cm}^{2} \mathrm{HP}$, $\mathrm{Hg}$ at $12 \mathrm{~cm} \mathrm{H}$ AP. In contrast to normals, $\mathrm{O}_{2} \mathrm{a}$ in the experimental group initially increased, then fell below the control levels at $9 \mathrm{~cm} \mathrm{H}_{2} \mathrm{O}$ AP, reaching $36 \%$ of control at $12 \mathrm{~cm} \mathrm{H}_{2} \mathrm{O}$ AP with $\mathrm{PaO}_{2}$ remaining almost within the control level. When $100 \%$
$\mathrm{O}_{2}$ was administered at $12 \mathrm{~cm} \mathrm{H}_{2} \mathrm{O}$ AP, $\mathrm{PaO}_{2}$ tn normal animals 1ncreased to 408

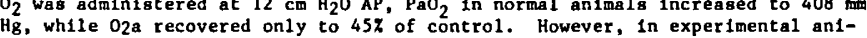
mals $100 \mathrm{O}_{2}$ increased $\mathrm{PaO}_{2}$ and $\mathrm{O}_{2} \mathrm{a}$ to $295 \mathrm{~mm} \mathrm{Hg}$ and $201 \%$ respectively. Changes in $\mathrm{BP}, \mathrm{Pes}, \mathrm{O}_{2}^{\mathrm{a}}$, and $\mathrm{PaO}_{2}$ produced by increasing AP from 0.5 to $12 \mathrm{~cm}$
$\mathrm{H}_{2} \mathrm{O}$ in a single animal from the normal group are shown in $\mathrm{Fig}_{\mathrm{g}}$. 3 . Each increment in AP produced a simultaneous increase in Pes and a decrease in $\mathrm{O}_{2} \mathrm{a}$, reaching a maximal change at $12 \mathrm{~cm} \mathrm{H}_{2} \mathrm{O}$, at which pressure $\mathrm{PaO}_{2}$ first showed a decrease. Although mean BP did not change, Pulsus Paradoxicus occured at 9 and $12 \mathrm{~cm} \mathrm{H} O \mathrm{OP}$. Contrary to this, in an experimental animal (Fig. 4) Pes and $\mathrm{O}_{2}$ a changed first at an AP of $9 \mathrm{~cm} \mathrm{H}_{2} \mathrm{O}$ reaching maximal changes at $12 \mathrm{~cm}$. $\mathrm{H}_{2} \mathrm{O}$ at which pressure $\mathrm{PaO}_{2}$ dect
sus Paradoxicus did not occur.

Under conditions of unchanged oxygen consumption, t1ssue $\mathrm{O}_{2}$ a 18 primarily affected by blood oxygen content and blood flow. If supposed that during the experiment, oxygen carrying capacity remains unchanged, then oxygen content primarily will be effected by $\mathrm{PaO}_{2}$. Therefore, the ratio of $\mathrm{O}_{2} \mathrm{a} / \mathrm{PaO}_{2}$ would re-

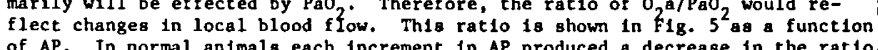
of AP. In normal animals each increment in AP produced a decrease in the ratio In experimental animals (low lung compliance) a noticeable decrease occurred
only when AP reached $12 \mathrm{~cm} \mathrm{H} \mathrm{H}_{2} \mathrm{O}$.

To further verify that the decrease in muscle $O_{2}{ }^{a}$ with excessive application of AP is not a local phenomenon, changes in cortical $\mathrm{O}_{2}^{\mathrm{a}}$ as a function of increase in AP were measured. In a representative single experiment performed on a normal animal (F1g. 6), each increment in AP produced a decrease in cortical $0_{2} a$, reaching a maximum decrease of 502 at $12 \mathrm{~cm} \mathrm{H}_{2} \mathrm{O} A P$. When $A P$ was dec
back to atmospheric, the cortical $\mathrm{O}_{2}$ a returned to its normal values. $0_{2} a$ as a function of increased AP in a single animal with different lung com-
p liance is shown in Fig. 7. In an animal with normal lung compliance $(9.0 \mathrm{cc} /$ 8) each increment in AP produced a decrease in $0_{2} a$. In an animal with oildiy $(7.5 \mathrm{cc} / \mathrm{g})$ and moderately $(5.0 \mathrm{cc} / \mathrm{g})$ decreased lung complance, an intelal increase in $\mathrm{O}_{2}^{\mathrm{a}}$ at 3 and $6 \mathrm{~cm} \mathrm{H}_{2} \mathrm{O}$ was followed by a decrease when greater AP was applied. It should be noted that as lung compliance decreased, a maximum $\mathrm{O}_{2}{ }^{\mathrm{a}}$ ed to produce optimal tissue oxygenation without interfering with tissue perfusion.

\section{DISCUSSION}

CPPB at 3-15 cm Ho AP was evaluated in animals with normal and low lung compliance. Animals with normal compliance could not tolerate any increase in AP. This was manifested by an immedlate increase in Pes and Pra and a decresse in $Q$ and $\mathrm{O}_{2} \mathrm{a}$ when as little $\mathrm{as} 3 \mathrm{~cm} \mathrm{H} \mathrm{H}_{2}$ was applied. Contrary to this, anlmals with low compliance lungs exhibited the protective "barrier effect". tolerat1ng much higher pressures. Pes and Pra 1 ncreased and $Q$ and $0_{2}$ decressed at
only $6-9 \mathrm{~cm} \mathrm{H} \mathrm{H}_{2} \mathrm{AP}$. Furthermore, at $12 \mathrm{~cm} \mathrm{H} \mathrm{H}_{2} \mathrm{AP}$, these changes were of less only 6-9 cm H $\mathrm{H}_{2} \mathrm{O}$ AP. Furthermore, at $12 \mathrm{~cm} \mathrm{H} \mathrm{O}_{2} \mathrm{AP}$, these changes were of less $\mathrm{PaO}_{2}$ and $\mathrm{O}^{\mathrm{a}}$ should be specifically emphasized. In the normal group, $\mathrm{O}_{2} \mathrm{a}$ de$\mathrm{PaO}_{2}$ and $\mathrm{O}_{2}^{\mathrm{a}}$ should be specifically emphasized. In the normal group, $\mathrm{O}_{2}^{\mathrm{a}}$ de-
creased with each increment in $\mathrm{AP}$, while $\mathrm{PaO}_{2}$ remained relatively unchanged. In the experimental group, $\mathrm{O}_{2} \mathrm{a}$ and $\mathrm{PaO}_{2}$ showed an initial Increase correspondIng to the optimal AP points. Further increase in AP produced a decrease in $\mathrm{O}_{2}^{\mathrm{a}}$. while $\mathrm{PaO}_{2}$ remained within the control level. $\mathrm{PaO}_{2}$ in both groups de-
creased only when an AP of $12 \mathrm{~cm} \mathrm{H} \mathrm{H}_{2} \mathrm{O}$ was reached. Administration of $100 \mathrm{z}$, creased only when an $A P$ of $12 \mathrm{~cm} \mathrm{H}{ }_{2} \mathrm{O}$ was reached. Administration of $100 \mathrm{Z}_{2} \mathrm{O}_{2}$ at this pressure increased $\mathrm{PaO}_{2} \mathrm{as} \mathrm{h1gh} \mathrm{as} 408 \mathrm{~mm} \mathrm{Hg}$ while $\mathrm{O}_{2} \mathrm{a}$ in control and experimental groups was $45 \%$ and $201 z$ of control respectively. This exemplifies that $\mathrm{PaO}_{2}$ can be at normal or hyperoxic levels while $\mathrm{O}_{2} \mathrm{a}$ is markedly decreased, suggesting a reduction in perfusion. The reduction in perfusion was of greate magnitude in animals with normal compliance lungs. Th1s is in agreement with the work reported by Suter et al (9) who observed that in patlents with low functional residual capacity and lung compliance, maximum oxygen transport was achieved at higher levels of positive end expiratory pressure. Improvement in
total lung compliance was accompanied by improvement in total oxygen transport total lung compllance was accompanied by improvement in total oxygen transport avallability which provides the evidence that at an optimal airway pressure the highest levels of tissue oxygenation are achleved.

Our data indicate the mechanism of reduction in perfusion is by means or pressure transmission across the alveolar wall, which in turn produces an increase In Pes, followed by an increase in Pra and a decrease in pulmonary venous return, $Q$, and $O_{2} \mathrm{a}$, and that this mechanism is compllance dependent. This suggests that for proper selection of a 1rway pressure, measurement of variables
which reflect changes in perfusion in addition to changes in systemic oxygenswhich reflect chang

Our data further Indicate that while the appearance of Pulsus Paradoxicus occurs later than changes in Pes, Pra, and $\dot{Q}$ when excessive AP lo applied, nevertheless it could be used as a warning aignal. However, because changes in $\mathrm{O}_{2} a$ occur concurrently with changes in $P e s, P r a$, and $Q$, we stress that a reduction
in $0_{2}$ a would accurately reflect excessive AP. Since changes in $Q$ during CPPB are compliance dependent and since $O_{2}$ is $\dot{Q}$ dependent, $O_{2} a_{\text {could }}$ provide a means of selecting optimal AP during CPPB. Therefore, we propose that in a clinical situation while continuously measuring muscle $\mathrm{O}_{2} \mathrm{~s}$, a pressure sweep
(Fig. 8) in the range from $0-15 \mathrm{~cm} \mathrm{H}$ O AP should be obtained. The initial increase in $\mathrm{O}_{2}$ a $1 \mathrm{~s}$ related to fmproved pulmonary performance (opening of atelectatic areas, decrease in pulmonary shunting). A succeeding decrease 18 related to a decrease in perfusion secondary to excessive increase in AP. The point on 
the curve where the slope equals zero $\left(\mathrm{dO}_{2} \mathrm{a} / \mathrm{dAP}=0\right)$, is considered the opt 1mal al rway pressure point, which produces the best transpulmonary gas exchange with the lest interference with tissue perfusion.

\section{REFERENCES}

1. Ashbaugh D.G., Petty T.L., Bigelow D.B., and Harris T.M. Continuous positive pressure breathing (CPPB) in adult respiratory distress syndrome. Journal of Thoracic and Cardiovascular Surgery 57:31 (1969)

2. Beran A.V., Strauss J., Sperling D.R., Norton A.C., Garwood V.P., and Yamazak1 J. Effect of thalidomide on brain oxygenation. Pediatric Research 5:199 (1971)

3. Beran A.V., Sperling D.R., and Huxtable R.F. Cardiopulmonary changes following 24-36 hours of hyperoxia. Avation, Space and Environmental Medicine. Apr11 (1975).

4. Gregory G.A., Kitterman J.A., Phibbs R.H., Tooley W.H., and Hatiliton W.K. reatment of the Idiopathic Respiratory Distress Syndrome with continuous pos tive alrway pressure. New England Journal of Medicine 284:1333 (1971).

5. Gribetz I., Frank N.E., and Avery M.E. Static volume pressure relations of excised lungs of infants with Hyal lne Membrane Disease, newborn and st111born infants. Journal of Clinical Investigation $38: 2168$ (1958).

6. Misrahy G.A., Beran A.V., and Hardw1ck D.F. Fetal and neonatal brain oxygen. American Journal of Physiology 203:160 (1962).

7. Strauss J., Beran A.V., Baker R., Boydston L., and Revs Sanchez J.L. Effect of hemorrhagic shock on renal oxygenation. American Journal of Physiology $221: 1545$ (1971).

8. Strauss J., Beran A.V., and Baker R. Continuous $O_{2}$ monftoring of newborn and older infants and of children. Journal of Applied Phys1ology 33:238 (1972).

9. Suter D.M., Falrley H.B., and Isenberg M.D. Opt Imum end-explratory a1rway pressure in patients with acute pulmonary fallure. New England Journal of Med-

10. Th1s work was supported by the National Institute of Health, National Heart, Lung, and Blood Institute Contract No1-5-2947.

11. Requests for reprints should be addressed to: A.V. Beran, Department of Pediatrics, College of Medicine, University of California, Irvine, California

12. Received for publication October 10, 1976.

13. Accepted for publication February 15, 1977.

TABLE I

\begin{tabular}{|c|c|c|c|c|c|c|c|c|}
\hline $\mathrm{AP} \mathrm{cm} \mathrm{H} \mathrm{H}_{2}{ }^{\circ}$ & & .5 & 3 & 6 & 9 & 12 & 12 & 12 \\
\hline $\mathrm{FiO}_{2} \mathrm{z}$ & & 20.9 & 20.9 & 20.9 & 20.9 & 20.9 & 50 & 100 \\
\hline \multirow[b]{2}{*}{$\mathrm{PaO}_{2} \mathrm{~mm} \mathrm{H}_{8}$} & $\mathrm{~N}$ & $96 \pm 7$ & $96-6$ & $98-5$ & $94 \pm 3$ & $88 \pm-10$ & $197 \pm 23$ & $408 \div 32$ \\
\hline & E & $46 \pm 9$ & $56 \pm 9$ & $55 \pm 11$ & $46 \pm 9$ & $39-8$ & $154 \div 55$ & $316 \pm-80$ \\
\hline \multirow{2}{*}{$\mathrm{O}_{2} \mathrm{az}$} & $\mathrm{N}$ & 100 & $92 \pm 10$ & $72 \pm 11$ & $55-10$ & $22 \pm 11$ & $40 \pm 13$ & $45_{-18}^{+}$ \\
\hline & E & 100 & $107 \pm 12$ & $100 \pm 21$ & $78 \div 20$ & $36 \div 17$ & $146^{ \pm} 144$ & $201 \pm 192$ \\
\hline
\end{tabular}

TABLE I. Ef fect of Increased proximal airway pressure (AP) on $\mathrm{PaO}_{2}$ and $\mathrm{O}_{2} \mathrm{a}$.
$\mathrm{N}=$ Normal group (normal lung. $\mathrm{E}$ - Experimental group (oxygen damaged lung).

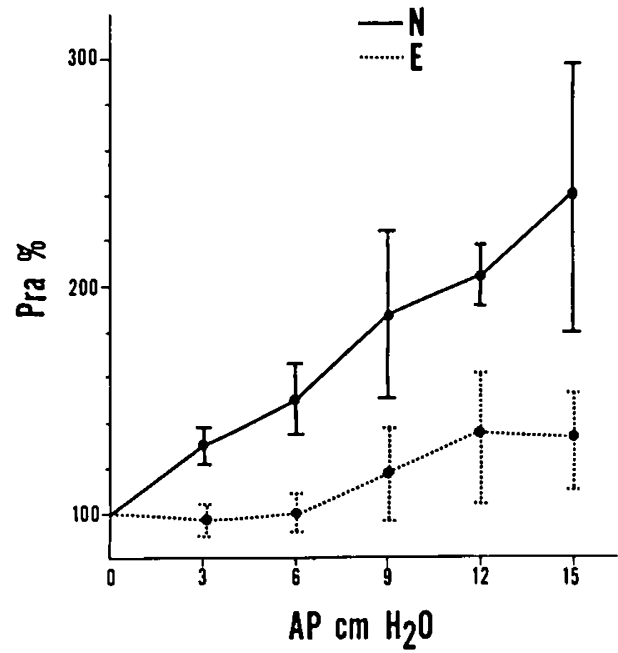

F1g. 1. Percent changes in right atrial pressure (Pra) as a function of increase in prexing (AP). N = Normal group (normal lung). $E$ Erease ln proximal alrway pressure (AP);.

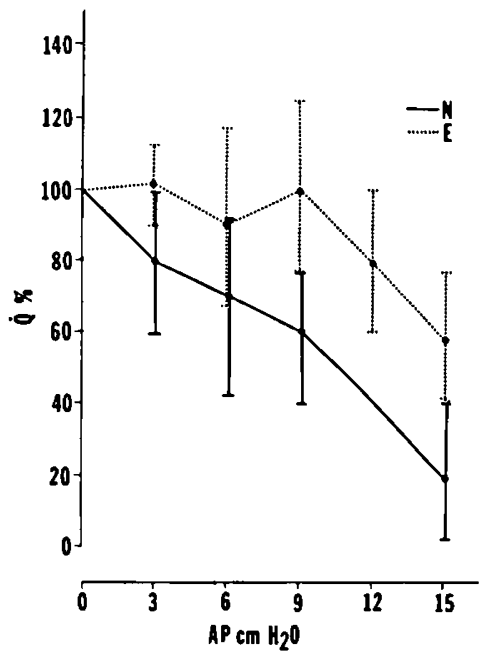

Fig. 2. Percent changes in cardiac output $Q$ as a function of increase in proxImal al rway pressure (AP). N - Normal group (normal lung), $E$ - Experimental group (oxygen damaged lung).

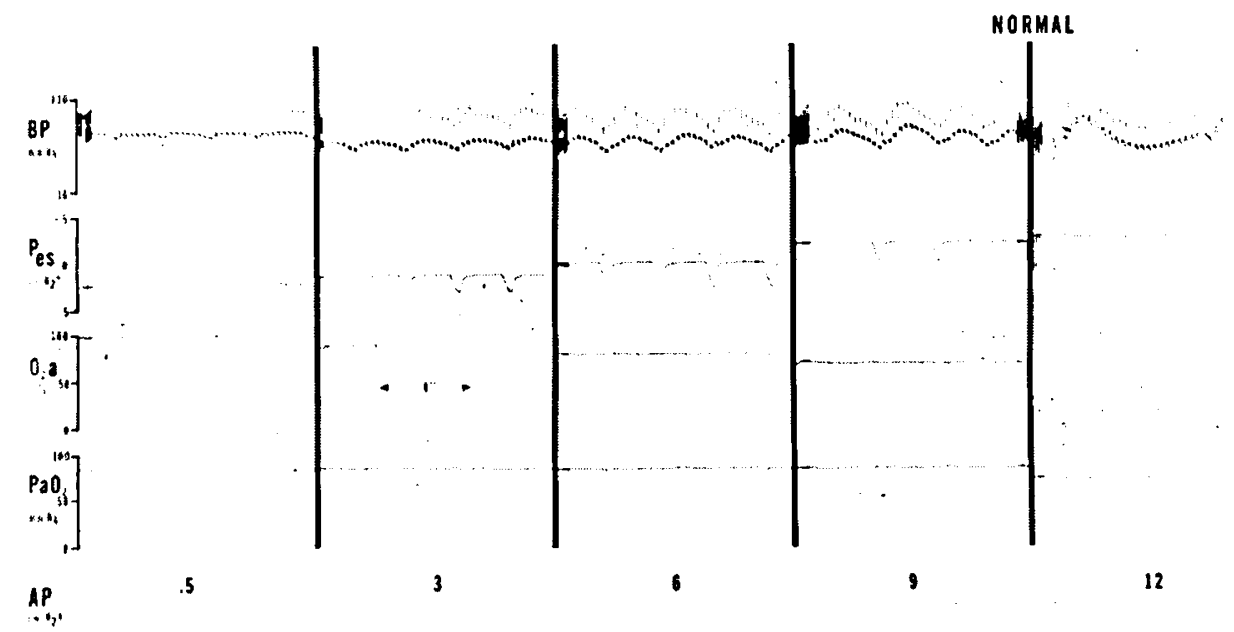

Fig. 3. Changes in $\mathrm{BP}, \mathrm{Peg}, \mathrm{O}_{2} \mathrm{a}$, and $\mathrm{PaO}_{2}$ produced by increasing proximal sirway pressure (AP) in a single animal from the normal group. 

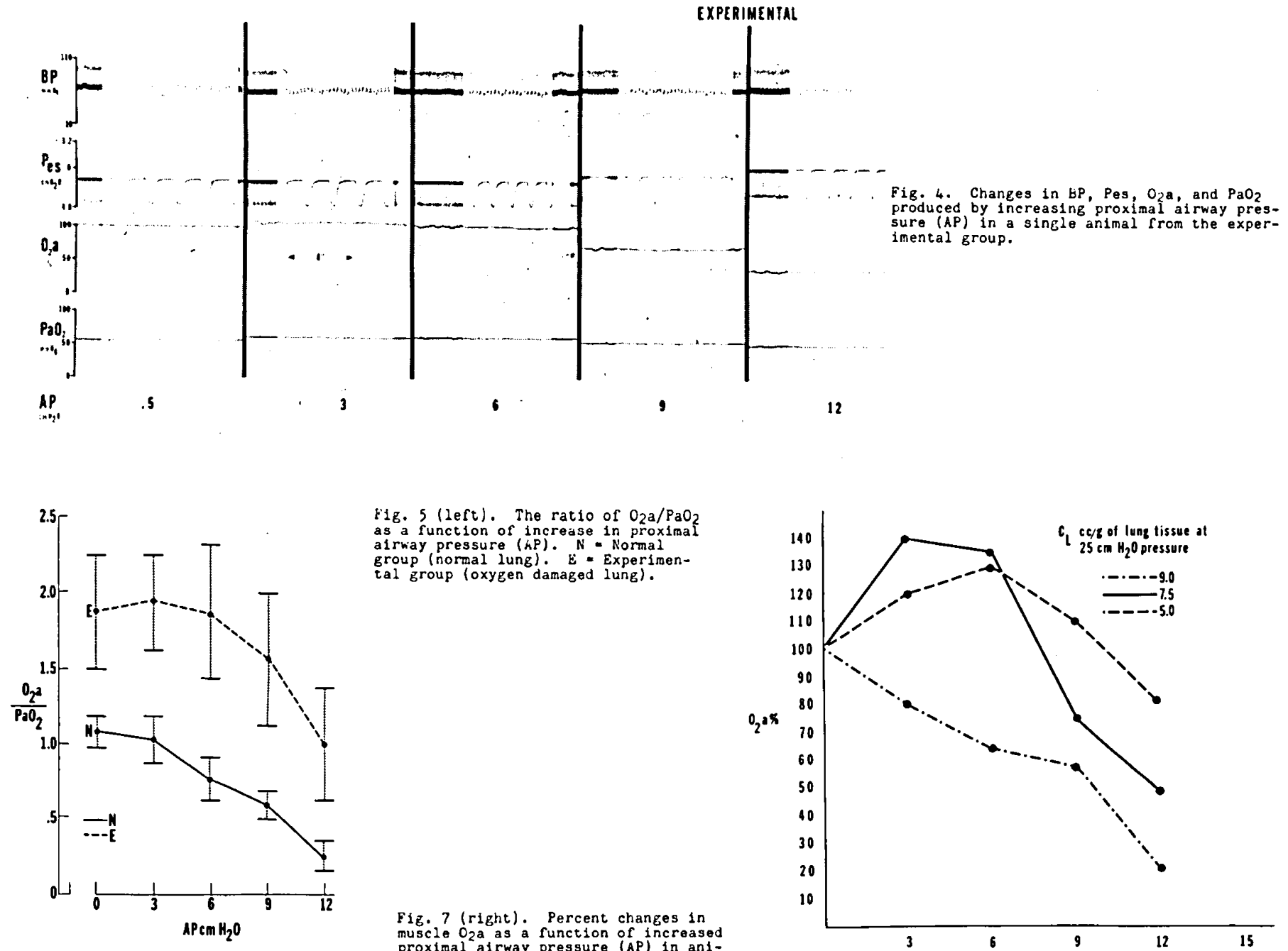
IIg. 5 (left). The ratio of $\mathrm{O}_{2} \mathrm{a} / \mathrm{PaO}_{2}$ alrway pressure ( $A P$ ). N - Normal group (normal lungl. Experimenal group (oxygen damaged lung).

Fig. 7 (right). Percent changes in muscle $\mathrm{O}_{2} \mathrm{a}$ as a function of increased mals with different lung compliances.
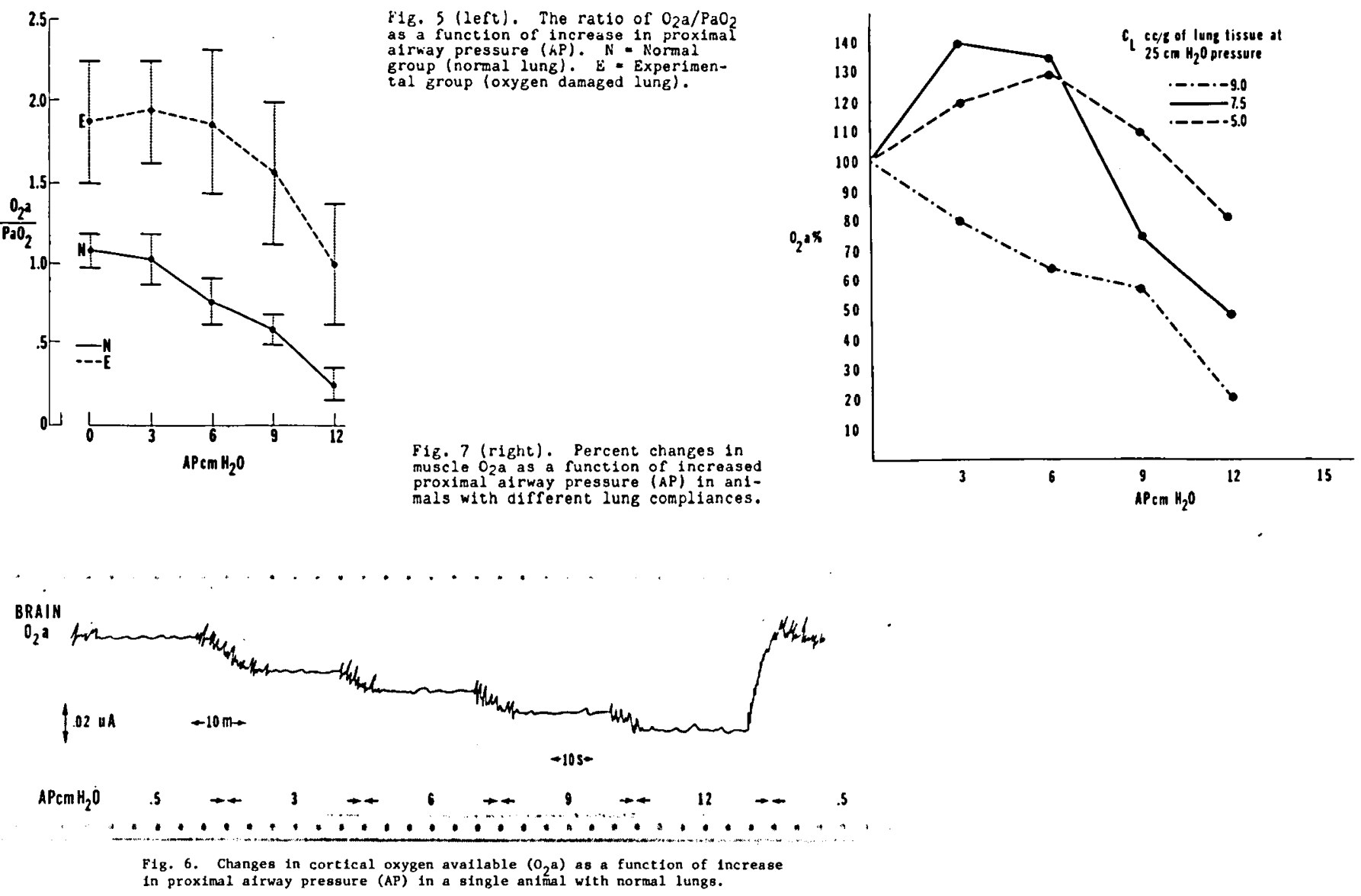

Fig. 6 . Changes in cortical oxygen avallable $\left(0_{2}\right.$ ) as a function of increase
in proximal afrway pressure (AP) in a single animal with normal lungs. increar function. Further 1ncrease in AP produces a decrease in tissue $0_{2}$ a a a result of decreased oxygen delfvery due to alveolar overdistension, resulting in decrease in putmonary venous return and cardiac output.

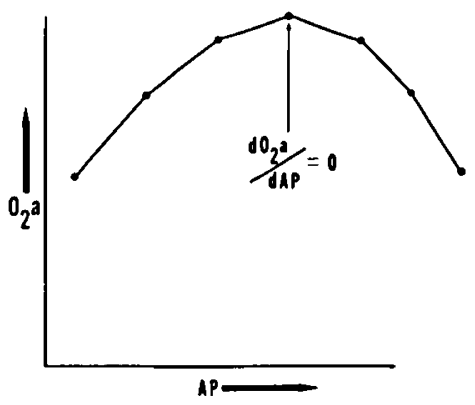

